\title{
A POSSIBLE IMPACT OF CULTURAL FACTORS ON THE EXPECTATIONS ON THE CONTENT OF ISLAMIC FINANCIAL STATEMENTS
}

\author{
Malgorzata M. Czerny, Marta Mazurowska \\ Poznan University of Economics and Business, Poland \\ E-mail: malgorzata.czerny@ue.poznan.pl, marta.mazurowska@ue.poznan.pl
}

\begin{abstract}
The financial reporting is considered to be a 'universal' language of business, the efforts to harmonize and standardize it are dictated by conviction, that the usefulness of financial and non-financial information delivered this way can be improved and might facilitate comparisons of companies operating around the world, etc. However, the real perception of information generated by financial statements is made by real people, not by the economic model of homo oeconomicus, that is why psychological and cultural factors are extremely important in the analysis of this process. There is a lack of comprehensive studies on this subject. Most of publications are contributory.

The research is based on the critical review of the subject literature and using mostly the method of induction, the impact of selected cultural conditions on the formulation of expectations on the content of the financial statements is examined and proved. The example of Muslim countries is used as the beginning of series of articles in the taken subject.
\end{abstract}

Keywords: accounting harmonization, cultural factors, decision-making, financial reporting, Islam.

\section{Introduction}

This research starts a series of studies in the scope of analysis of perception of information delivered by financial reports - in theoretical, cultural and behavioral terms. Present research aimed to prove the impact of selected cultural factors on the formulation of expectations on the content of the financial statements. In this research only designated example of the cultural circles is examined (Islamic countries). This problem is especially important in the context of progressing work on standardization and harmonization of accounting, as evidenced in last decades.

Financial reports provide a large amount of specialized and at the same time complex information about the company. The stakeholders, investors or just receivers of financial reports are assumed to study them, analyze, draw conclusions. There is obvious that not all of them have sufficient knowledge to do it 'properly'. But it is also quite obvious, that not only lack of some knowledge is a reason of different interpretation of information included in the financial statements by various readers. These reasons have also some other background, i.e. cultural one, and very often one results from the other.

The International Accounting Standards Board has been working by many years on improving the usefulness of financial statements. The 'usefulness' is a keyword here. The accounting, and especially financial reporting, are considered to be a 'universal' language of business, the efforts to harmonize and standardize them are dictated by conviction, that the usefulness of financial and non-financial information delivered this way will be improved, that it will facilitate comparisons of companies operating around the world, etc. But, the usefulness of information contained in these more and more unified reports is still evaluated differently by 
Malgorzata M. CZERNY, Marta MAZUROWSKA. A possible impact of cultural factors on the expectations on the content of Islamic financial statements

OF MANAGEMENT

IN THE $21^{\text {st }}$ CENTURY Vol. 14, No. 1, 2019

22

their receivers, because their expectations are and probably always will be quite different, for various reasons.

This research tries to find an answer, if these different expectations can remain a significant obstacle for further standardization and harmonization of financial statements, as well as to analyze their possible cultural determinants. This problem appears in some scientific researches quite frequently, but it's still not fully recognized.

\section{A Brief Literature Review}

Accounting diversity appears as the differences existing between the characteristics of the financial reporting frameworks used in different countries. It is a result of the factors affecting the development of financial reporting frameworks. The accounting literature presents at least several of such factors, mainly related to environmental determinants of the development of accounting systems (Alia \& Branson, 2011). It is important to understand, that these environmental factors, like culture, cause some limitations in the pursuit of international accounting harmonization.

This research focuses on environmental factors mostly. These are considered though to be the major reason for an international accounting diversity. The accounting rules and practices are influenced by a large number of quite different factors, and particularly important and often referenced are: the political and the economic system, the legal system, the taxation system, the corporate financing system, and the accounting profession (Baker \& Barbu, 2007; Roberts et al., 2005). Some authors take into consideration also cultural environment and its influence. One of them is Nobes (1983), whose model uses a two-way classification based on the strength of equity markets and the degree of cultural dominance to explain the reasons for international differences in accounting practices. Nobes indicated the political system, religion and the stage of development as the main determinants of differences (Alia \& Branson, 2011).

The most known studies about the relations between the financial reporting framework and cultural environment though, are by Hofstede (Hofstede, 1980; Hofstede 1983; Hofstede, 1984) and Gray (Gray, 1988). Hofstede (Hofstede, 1984) identified culture as the collective 'programming of the mind' which distinguishes the members of various communities. His four dimensions of international differences in cultural values relate to the environment of local financial reporting framework (Alia \& Branson, 2011). These are: large versus small power distance, strong versus weak uncertainty avoidance, individuality versus collectivism and masculinity versus femininity. In turn, Gray (1988) claimed that the differences in accounting systems and as well financial reporting frameworks are caused by: variety of legal systems, economic circumstances, corporate financing, the size and authority of the accounting profession, and national culture. He tries to find an answer, if the international differences in accounting may be explained and predicted by differences in cultural factors. Using Hofstede's cultural dimensions, Gray identified four accounting subcultural dimensions: professionalism versus statutory control, uniformity versus flexibility, conservatism versus optimism and secrecy versus transparency. The first two dimensions describe attitudes toward regulation and the type (or level) of preferred control. The third dimension is concerned with attitudes towards measurement, while the fourth dimension is related to attitudes towards disclosure.

The Hofstede-Gray model has been used in some studies to examine the effect of culture on accounting (Askary, 2006a; Askary, 2006b; Baydoun \& Willett, 1995; Baydoun \& Willett, 1997; Hamid et al., 1993; Jaggi \& Low, 2000; MacArthur, 1996; Perera \& Baydoun, 2007). Also, the effect of culture on accounting harmonization is highlighted in the literature, however, not in Poland. In general, researchers who consider this problem, agree that culture influences how people perceive situations and organize institutions, so there must be also some impact of it on accounting. For example, Archambault and Archambault (2003) found a strong relationship between disclosure and cultural systems. Baker and Barbu (2007) notice the possible effect of culture on the success or fall of international accounting harmonization, while Askary (2006a) 
argued that the culture (as a national system consisting of language, religion, morals, values, attitudes, law, education, politics, social organization, technology, and also material culture) may just prevent the global unification of accounting practices. These authors conclude that acceptance of mandated disclosures may meet with resistance, arguing variously.

From other side, A. Belkaoui, constructing his own accounting development model, assumed that culture defines the process of evaluating accounting, because through its components (dimensions) "it composes the organizational structure, micro-organizational behaviors and cognitive functions of individuals" (Belkaoui, 1995), thus affecting the opinions and decisions of these units. This author also formulated the thesis about the cultural relativism of accounting, referring this phenomenon to the need to assess every human behavior in relation to one's own pattern (cultural context) (Belkaoui, 1995). The study of cultural and intercultural issues in this context has a fundamental impact on understanding the determinants of the differences between national accounting systems, because the basic assumption is that the accounting concept in each country is unique, just as the cultural characteristics are unique. A. Belkaoui in his model presented a way of subordinating the processes of adjudication and deciding in cultural dimensions, proving that they exert influence on organizational structures, micro-organizational behaviors and cognitive functions of individuals, thanks to which they become appropriate for a given cultural circle.

In the researchers' opinion, a key is, that a culture influences an accounting as a system (framework), as well as a 'pattern of thinking and understanding', it thus impacts on this, how financial reports are composed and also how the receivers read them. If standardized financial reports do not meet receivers' expectations, there indeed can be assumed that they will resist the further harmonization and standardization of accounting.

Between cultural factors, a religion is the main cultural component; it affects the financial reporting framework, but it affects also expectations regarding its content (an information). A good example here are Islamic financial reports and their users. The expectations formulated by receivers of financial statements are a part of general problem of judgement and decisionmaking in accounting, moreover in case of Muslim countries the influence of religion on this process is particularly noticeable.

\section{Decision-Making Process in Accounting}

Every human activity as well as an activity of individual organizations are based on continuous decision-making process (Ściborek, 2003). According to the literature on the subject, decision-making is a process that involves recognizing and selecting a specific course of action to solve a specific decision problem (Stoner et al., 2001).

An exceptionally interesting and important area of research on decision-making is research on Judgment and Decision-Making (JDM), which aims to provide research results that will allow to understand and improve the process of making professional judgment and decision-making by people.

Social sciences have developed two scientific approaches to the theory of decisions that in reality permeate each other. These include the approach (Bolesta-Kukułka, 2003):

- rationalistic-normative (prescription), consisting in the recommendation of universal prescriptions that people should follow in their actions,

- behavioral (description), consisting in presenting how people behave in reality.

The rationalistic-normative approach, which is based mainly on indications resulting largely from logic, mathematics and statistics, contains logically derived from the a priori adopted norms of rationality: conditions, rules and recommendations that must be followed so that decisions are made consciously and intelligently. If in reality the behavior of the decisionmakers appears a deviation from these principles, they are explained by the errors of thinking resulting from the imperfections of human thinking (Grzesik \& Karaś, 2014). 
Malgorzata M. CZERNY, Marta MAZUROWSKA. A possible impact of cultural factors on the expectations on the content of Islamic financial statements

OF MANAGEMENT IN THE $21^{\text {st }}$ CENTURY Vol. 14 , No. 1, 2019

In turn, the behavioral approach presents the actual behavior of decision-makers, which do not always coincide with the recommendations of rationalistic-normative models. Such deviations occur frequently, which is why they are difficult to interpret as a negative phenomenon. The authors of the recommendations in the framework of the discussed approach not only describe decision-making behaviors, but also try to discover the reasons for the deviations found. In behavioral models, attention is directed primarily to describing and explaining real decision processes that, in fact, run differently than the norms contained in rational models (Grzesik \& Karaś, 2014).

The assumptions of prescription theory can also be found in economic sciences, in the form of the paradigm of homo oeconomicus. This paradigm is recognized in the classical school and its continuations as an assumption enabling the formulation of theoretical generalizations. This concept was created in the second half of the seventeenth century by a Scottish philosopher regarded as the father of economics A. Smith, who explaining the mechanism of the 'invisible hand of the market', relies on him, although he was not named by him at the time. To economics, the homo oeconomicus model was introduced by Mill (1882).

The abstract homo oeconomicus assumption states that specific human behavior in the sphere of management can be explained in terms of strictly rational choices (Wach, 2010).

Swacha-Lech (2010), to the main features of the homo oeconomicus model approach classifies:

- maximizing usability,

- optimal operation in an arbitrary environment,

- permanence and continuity of preferences,

- independence of general preferences from the context,

- analytical information processing,

- unrestricted availability of information,

- a universal and homogeneous decision-making mechanism,

- the original role of cognitive processes,

- unlimited willpower,

- unlimited selfishness.

The subject of the sense and correctness of the assumption about the rationality of economically profitable economy has strengthened again in the last decade, where the crisis has exposed serious weaknesses in the mainstream of economics in explaining the causes of the crisis, its course and its potential effects. Significantly, serious accusations against one's own discipline are also formulated by eminent scholars belonging to the mainstream of economics. They emphasize that mainstream economics had little to say about some phenomena and dependencies, which in the crisis were very important (Wojtyna, 2011).

Therefore, the researchers bowed to considering factors that in fact affect decisions made by economic agents. An extremely interesting area of research are the factors influencing the decision-making in accounting, which are the subject of this article.

\section{The Role of Research on Judgment and Decision-Making Process in Accounting}

Scientific research on decision-making in financial accounting is designed to answer the fundamental question, whether accounting practice affects the behavior and decisions of receivers of the information generated by it. Assuming the full market perfection (complete and perfect markets) there is no substantive justification for the role of disclosure of information in the financial statements, and thus there is no demand for accountants and regulations accounting. This dependence has been proved, among others in the results of the research by Watts and Zimmerman (1979) or by Holthausen and Leftwich (1983). Watts and Zimmerman research was especially significant here (Watts \& Zimmerman, 1986). However, in the economic reality the assumption about the excellence and completeness of markets is not met, and therefore the demand for accounting, its regulations and people dealing with accounting means that disclosure in accounting is an effective way to solve market imperfections (Fields et al., 2001). 
According to the literature, a choice in accounting is a decision whose primary purpose is to exert influence in a predetermined manner (both through form and content) on information generated by the accounting system, including not only financial statements published in accordance with the adopted accounting regulations, but also tax declarations and other reports (Fields et al., 2001). The above definition is broad enough to include choices such as the use of the FIFO or LIFO method for stock removal, the use of historical cost or fair value for the valuation of investment properties, shaping the lease contract structure, choices affecting the level of disclosure or previous application of new ones standards. This definition also takes into account decisions regarding the entity's business operations, the impact of which naturally translates into the values shown in the financial statements. An example of such a decision is a dilemma regarding increasing production in order to reduce the cost of sold elections by reducing unit fixed costs or expenditure on research and development in order to increase the financial result.

As stated by Watts (1992), the process of making accounting choices should be at the center of accounting science, because without the ability to explain and anticipate the decisionmakers and the consequences of their decisions, it will be impossible to either understand the accounting properly or transfer the proper knowledge students.

Taking all above mentioned into consideration, there are many factors that distort human cognitive abilities, among others: limited human ability to process information, reduced mental effort, emotions, motivations or time pressure. In order to reduce the complexity of the process of formulating judgments and making decisions, people use heuristics, and as a result often fall into various types of cognitive traps. It is important to know them, control them and limit their impact. The mental processes have a very individual character. Research on cognitive aspects in accounting is therefore quite complicated. As stated by Artienwicz (2011), a lot of elaboration and consideration concerns the methods of valuation and presentation of individual balance and result categories, however, it is often forgotten that this presentation and valuation is made by a human being. Therefore, the application of a behavioral approach to accounting science is highly justified.

In the context of decision-making in accounting by real decision-makers, with particular emphasis on financial reporting, the influence of culture on the decision-making process, which is inherent in psychological factors, is extremely important.

\section{The Impact of Culture on Decision-Making Process in Accounting}

Cultures are traditions of thought and behavior that are (imperfectly) shared across the members of a community and transmitted in time across generations (Shweder \& LeVine, 1984). As stated by Odongo (2016), culture has a significant influence on people's judgement and decision-making process. Culture influences not only how people act, but also how they think, how they formulate views, but most importantly, how they evaluate and choose between different alternatives. According to Odongo, the relations between culture and decision making are as follows:

(a) there are indeed cultural differences in the world which impact on the way people make judgements and arrive at decisions;

(b) individuals are affected and influenced by their national cultures; and

(c) individuals who ultimately make decisions also bring on their personal characteristics. The challenge, however, is to find a way to clearly link these three aspects.

Although traditionally cultural psychology and Judgement and Decision-making (JDM) scarcely overlapped, analysis of representative journals suggests that interest in culture within Judgement and Decision-Making process is increasing; the culture literature features increasing rates of social choice ( $11 \%$ vs. $15 \%)$ and economic choice ( $2 \%$ vs. $3 \%)$ research and, correspondingly, the rate of culture-focused research is increasing in the social JDM ( $1 \%$ vs. $5 \%$ ) and economic JDM fields (2\% vs. 3\%) (Weber \& Morris, 2010). 
Malgorzata M. CZERNY, Marta MAZUROWSKA. A possible impact of cultural factors on the expectations on the content of Islamic financial statements

AGEMENT

IN THE $21^{\text {st }}$ CENTURY Vol. 14 , No. 1, 2019

As it has been mentioned above, there is no doubt that many of the cultural determinants impact not only the human mind, but also the shape of an economy. The impact of cultural factors on the economy, as well as its specific fields, including accounting, has been studied, among others, by Nobes (1998), Hofstede (1980) and then by Gray (1988) and Belkaoui (1995). Lately, some reflections on the topic have also appeared in the Polish literature (Adamek, 2011a; Adamek, 2011b; Adamek, 2012; Kamela-Sowińska, 2006). It is noteworthy that at the same time this problem began to be considered in scientific articles on management or financial sector and in many aspects (Bonca, 2010; Gorzeń-Mitka, 2015; Kaźmierczyk, 2008).

Cultural, social, economic and political factors (different in many countries) have a significant impact on expectations formulated in relation to financial statements in terms of information that they should provide as well as tasks faced by the accounting system. Each country uses the accounting system, despite its far-reaching standardization, in a manner adapted to the specificity of these factors, harmonized with the general principles on which the functioning of the economic system is grounded (Adamek, 2012; Diaconu \& Coman, 2006). The literature and business practices reveal the necessity of maintaining high ethical standards in accounting, information and auditing system of the past and present financial management of the economic entities/organizations. One of the driving cultural factors is religion, cultivating ethical attitudes through the transfer of certain values that become the basic principles for individual actions influencing the applicable standards in a given society (Czerny, 2015a; Czerny, 2015b). Religion can be held, at least, partially responsible for such ethical accountability. But it can also affect the way of reading and understanding the financial reports, due to some expectations of readers about usefulness, importance of information, so also an assessment of it. Due to the role, that accounting has to fulfil, the reliability of the information provided by it is an indispensable condition of its existence and the demand for data generated by this system. This reliability is also necessary for the justification of the privileged status of the accounting profession in the public service, with trust and honesty as its foundations. An individual's ethics is an internal belief system that determines how this individual perceives the world; the impact of the external environment in this area is undisputed (Czerny, 2015a). It harmonizes well with the general JDM theory.

\section{The Influence of Religion as a Culture Factor on Expectations of Muslim Financial Reports' Receivers}

The development of accounting systems in the countries with different cultural determinants, where value systems developed on the basis of Christian beliefs, Islam, Confucian philosophy or Buddhism, indicates that religion unambiguously (though to a varying degree) affects the practice in this field. In this study the Muslim countries were chosen as a specific example of it.

Islam, as its faithful emphasis, is actually more than just a religion; it is a culture, a worldview and a lifestyle for the faithful to practice (Hamid et al., 1993). Islam interferes in many manifestations of its followers' activity and therefore affects the way in which the business is conducted. Unique solutions in the ways in which the businesses are conducted, and the bookkeeping practices in Muslim society are a great example of how far accounting can be integrated into fundamental religious principles (Maali \& Napier, 2010). In Islam earthly life is connected with the spiritual and religious spheres, everyday actions prepare the faithful for "higher" acts of a spiritual dimension. This also applies to business activity and, therefore, accounting (Afifuddin \& Siti-Nabiha, 2010). Sharia law formulates special demands with regard to financial practices, absolutely binding for followers and forming an original model, different from the Western one, of the functioning of economic systems in Muslim countries. These postulates also have a significant impact on accounting standards, its practices and the formula of financial statements. They come down to three prohibitions (Adamek, 2012; Bonca, 2010; Czerny, 2015b; Moin, 2013; Samad, 2004): 
- the prohibition of riba (interest) - no possibility of charging interest,

- the prohibition of gharar (speculation) - any activity involving speculative risk is prohibited and the faithful are obliged to avoid it; speculation in essential necessities and natural resources is particularly disgraceful,

- the prohibition of involvement in the production or consumption of goods that are haram (prohibited from the religious point of view).

To these prohibitions is attached one obligation - the payment of zakat (a kind of tax).

The accounting system in Muslim countries has developed and formed on the basis of the above-presented principles, hence its considerable difference from Western standards. The basic discrepancy in the perception of the need to comply with certain standards and solutions as well as in the attitude towards their formulation and refinement between the representative of the Islamic world and the West results from a completely different perception of the law $(\mathrm{Cz}-$ erny, 2015a). In the West, laws are made to adapt to the existing situation, to regulate it, while in the Muslims' opinion it is the situations that need to be shaped in order to conform to the Law of God (Mutahhari, 1993). At the same time, as in all major religions, Islam requires ethical behavior in contacts with others (responsibility and ethics are highly valued in this culture) and respect for resources. Islam accepts ownership in various forms without favoring one of them (As-Sadr, 1994). All property belongs to God, man is only its trustee; the ownership of the property is connected with obligations towards other people and consideration of their rights; however, the scope of ownership (of any type) may be changed and interpreted depending on the needs and circumstances. The principle of limited economic freedom follows indirectly from this fact. Everyone is a guardian of social trust and individual property rights should be limited by the public interest. The success of the individual and society depends on the balance between the spiritual and material needs of man. The system of distribution of goods and capital in Islamic society accepts differences in wealth but rejects excessive social stratification. Fair distribution of income is implemented by means of the prohibition of charging interest and the obligatory zakat tax (Czerny, 2015a).

Therefore, in Muslim countries, stakeholders and other users of financial reports expect, that accounting will provide primarily the financial information relevant to government and society as a whole (i.e. the major users of financial statements). Moreover, the fundamental issues are tax revenues, such as zakat and others, as well as the manner of their spending. The Islamic accounting model is therefore based on macroeconomics and financial statements are read, most of all, in such context. On a micro scale, Islamic financial statements from the point of view of Muslim user, must provide information about the economic and social significance of decisions made in a given business entity, useful for assessing the efforts of the management and all company employees made in order to exploit the resources necessary to achieve the company's business and social goals in accordance with legal, but also ethical standards. In addition, financial statements should provide information allowing for the assessment of management effectiveness in the field of income distribution in terms of achieving economic justice. The financial report should include a full and fair picture of the company and its activities in accordance with the principles contained in Sharia law. All activities that are not compliant with this law are haram, and therefore, considered illegal and immoral (Baydoun \& Willett, 1997). At this point, Sharia law is a reflection of principle of true and fair view (Czerny, 2015a).

Another characteristic of this accounting system is the fact that it is based on the theory of ownership. This is because in Islam as a canon of principles, everyone is responsible for their own actions-religious negligence as well as economic and financial activities in which they are engaged. There should be no separation between an enterprise as an economic entity and its owner, who as the owner of assets is responsible for liabilities and receivables. It would be immoral then to release the owner from liability for company debts while maintaining the right to profit. It would be a kind of forbidden speculation (the possibility of obtaining benefits excessive in relation to the risk undertaken) (Belkaoui, 1993; Khan, 1994). The consequence of accepting the theory of ownership is the recognition of the balance sheet as the most important 
Malgorzata M. CZERNY, Marta MAZUROWSKA. A possible impact of cultural factors on the expectations on the content of Islamic financial statements

PROBLEMS

IN THE $21^{\text {st }}$ CENTURY Vol. 14, No. 1, 2019

28

among financial statements (the static approach). The interaction between the company and the environment is closely monitored by users of financial statements in the social context, especially the income distribution mentioned above. In this model the profitability of the enterprise is a derivative of responsible management of assets and liabilities and keeping the balance between assets and liabilities. In opinion of Muslims, the perception of business activity through the prism of revenues and costs orients accounting towards cost management (striving to minimize costs), which often leads to 'inhuman conduct' (Adamek, 2012). Rules that are not in line with Islamic teaching, i.e. the historical cost, should not be the basis for property valuation; hence, valuation should be carried out, for example, based on current exit prices (Gambling \& Karim, 1991).

One of the fundamental differences between the Western and Islamic economies, reflected in the formation of the accounting system, is also the approach to tax issues. In Western countries, the tax is treated as a burden that companies should avoid if possible (which results from the focus on profit and assessment of the effectiveness of business operations from this perspective). For a Muslim, zakat is alms which the people poorer than the ones whose assets exceed a certain limit are entitled to. It is collected and distributed by the state which implements the principle of social justice; tax evasion or attempts to reduce the amount of tax paid are both a sin and an impoverishment of society, and cannot be considered legal (Czerny, 2015a). So low tax burden in the financial report of an entity will be treat by users with some dose of distrust and interpreted negatively. It cannot be another way, taking into consideration that an obligation of paying zakat is one of pillars of Muslim religion, and it is mentioned on the list of faithful duties immediately after the duty of daily prayer.

The obligation to pay zakat causes a problem for Muslim accountants as well, as the zakat rules are inconsistent with the generally accepted accounting practice (GAAP). The zakat concept is incompatible with the precautionary principle. It claims that while carrying out valuation, one should ensure that the value of assets and revenues is not overstated, and liabilities and costs are not understated. However, lowering the value of assets would mean a lower tax liability. In the context of the tax-related approach shortly discussed above (Islam encourages generosity), it would be a sin. By nature, the Muslim accountants will focus on avoiding underestimating the value of assets or inflating the value of liabilities, acting against the precautionary principle.

Due to the absolute necessity of observing religious norms, a different purpose of financial statements and the hierarchy of their users in Muslim countries, 'conventional' financial statements cannot be applied there. They will not fulfill expectations of users, regarding the information contained in them and primarily its utility in context of this what is ,moral” and what is not. Hence the consistent development by the Accounting and Auditing Organization for Islamic Financial Institutions in recent years of its 'own' accounting standards, is in line with Sharia law, which is to apply in all Muslim countries (Czerny, 2015a).

\section{Conclusions}

The Islam as a religion influences a worldview and a lifestyle of people born and raised in this cultural circle and in accordance with the JDM theory is shaping also their assessment, judging and expectations about i.a. accounting as a system of information. This way, a culture (religion) has an impact on the frames of this system. A shape of Muslim social economy forces a specific shape of accounting (financial statements). In turn, the shape of Islamic economy is dictated by Sharia law. An impact of beliefs is visible in a way the Muslim users are reading and evaluate financial statements, the main product of accounting system. It happens in terms of observing religious norms, so judgement is done through the prism of 'morality' or 'immorality', as well as expectations of users are formulated in terms of social justice, with mostly macroeconomic approach and acceptation of limited economic freedom. Financial reports not meeting these expectations will have - from the point of view of users - limited usefulness. 
That shows that standardization and harmonization of accounting in at least Muslim cultural circle face obstacles which have a cultural and at the same time also psychological background and are justified by less usability of unified financial reports. These findings do not exhaust the scope of research in the analyzed field. Subsequent publications will be an extension of the analysis of the relationship between culture and JDM in accounting, which will be supported by empirical research in the area of selected cultural circles.

\section{References}

Adamek, J. (2011a). Kultura a rachunkowość [Culture and accounting]. Prace naukowe Uniwersytetu Ekonomicznego we Wrocławiu, 193, 122-134.

Adamek, J. (2011b). Kulturowe uwarunkowania krajowych systemów rachunkowości w świetle koncepcji wymiarów subkultury rachunkowości S. Graya [Cultural conditions of domestic accounting systems in the light of the accounting subculture's dimensions of S. Gray]. Zeszyty Teoretyczne Rachunkowości, 62(118), 7-22.

Adamek, J.(2012). Kulturowe uwarunkowania rachunkowości wświetle założeń ipraktyki rachunkowości islamskiej i chińskiej [Cultural conditions in light of the Islamic and Chinese accounting principles and accounting practices]. Warsaw: CeDeWu.

Afifuddin, H. B., \& Siti-Nabiha, A. K. (2010). Towards good accountability: The role of accounting in Islamic religious organisations. World Academy of Science, Engineering and Technology. International Journal of Social, Behavioral, Educational, Economic, Business and Industrial Engineering, 4(6), 1141-1147.

Alia, M. J., \& Branson, J. (2011). The effect of environmental factors on accounting diversity. A literature review. Bedrijfskunde, 31(2), 23-34.

Archambault, J. J., \& Archambault, M. E. (2003). A multinational test of determinants of corporate disclosure. The International Journal of Accounting, 38, 173-194.

Artienwicz, N. (2011). Możliwości badania zachowania księgowych w świetle paradygmatów rachunkowości [Possibilities of studying the behaviors of accountants in the light of accounting paradigms]. Prace i Materiaty Wydziału Zarzadzania Uniwersytetu Gdańskiego nt. Kluczowe problemy teorii i praktyki rachunkowości, 1, 355-363.

Askary, S. (2006a). Accounting measurement in the religious perspective: Conservatism or optimism? IPA Conference papers. Wales: Cardiff, 2006, 1-11.

Askary, S. (2006b). Accounting professionalism - a cultural perspective of developing countries. Managerial Auditing Journal, 21(1), 102-111.

As-Sadr, M. B. (1994). Itisaduna [Our economic]. Teheran: World Organization for Islamic Services.

Baker, C. R., \& Barbu, E. M. (2007). Evolution of research on international accounting harmonization: A historical and institutional perspective. Socio-Economic Review, 5(4), 603-632.

Baydoun, N., \& Willett, R. (1995). Cultural relevance of Western accounting systems to developing countries. ABACUS, 31(1), 67-92.

Baydoun, N., \& Willett, R. (1997). Islam and accounting: Ethical issues in the presentation of financial information. Accounting, Commerce \& Finance: The Islamic Perspective, 1(1), 1-25.

Belkaoui, A. (1993). Accounting theory. New York: Dryden Press.

Belkaoui, A. (1995). A cultural shaping of accounting. Westport: Quorum Books.

Bolesta-Kukułka, K. (2003). Decyzje menedżerskie [Managerial decisions]. Warsaw: PWE.

Bonca, M. (2010). Islamskie instrumenty finansowe [Islamic financial instruments]. Warsaw: Wydawnictwa Akademickie i Profesjonalne, Akademia Leona Koźmińskiego.

Czerny, M. (2015a). Wpływ zasad religijnych na ukształtowanie systemu rachunkowości [The influence of religious principles on the formation of the accounting system]. Annales. Ethics in Economic Life, 19(2), 111-128.

Czerny, M. (2015b). Wpływ zasad religijnych islamu na sprawozdania finansowe - zarys problemu [The influence of Islamic religious principles on financial statements - the outline of the problem]. In Kamela-Sowińska, A. (Ed.), Teoria i historia rachunkowości. Rachunkowość Warta Poznania (19-27). Poznań: Wydawnictwo Uniwersytetu Ekonomicznego w Poznaniu.

Diaconu, P., \& Coman, N. (2006). Accounting research from the globalization perspective. International Journal of Human and Social Sciences, 1(1), 569-575.

Fields, T. D., Lys, T. Z., \& Vincent, L. (2001). Empirical research on accounting choice. Journal of Accounting and Economics, 31, 255-307. 
Malgorzata M. CZERNY, Marta MAZUROWSKA. A possible impact of cultural factors on the expectations on the content of Islamic financial statements

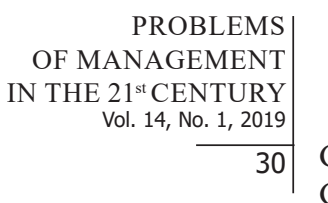

30

Gorzeń-Mitka, I. (2015). Management challenges in the context of risk culture. Problems of Management in the 21st Century, 10(2), 77-87.

Gray, S. J. (1988). Towards a theory of cultural influence on the development of accounting systems internationally. ABACUS, 24, 1-15.

Grzesik, K., \& Karaś, M. (2014). Decyzje menedżerskie w organizacji [Managerial decisions in the organization]. Wrocław: Wydawnictwo Uniwersytetu Ekonomicznego we Wrocławiu.

Hamid, S., Craig, R., \& Clarke, F. (1993). Religion: A confounding cultural element in the international harmonization of accounting? ABACUS, 29, 131-148.

Hofstede, G. (1980). Culture's consequences: international differences in work-related values. Beverly Hills CA: Sage.

Hofstede, G. (1983). The cultural relativity of organizational practices and theories. Journal of International Business Studies, 14(2), 75-89.

Hofstede, G. (1984). Cultural dimensions in management and planning. Asian and Pacific Journal of Management, 1(2), 81-99.

Holthausen, R., \& Leftwich, R. (1983). The economic consequences of accounting choice: Implications of costly contracting and monitoring. Journal of Accounting and Economics, 5, 77-117.

Jaggi, B., \& Low, P. Y. (2000). Impact of culture, market forces, and legal system on financial disclosures. The International Journal of Accounting, 35(4), 495-519.

Kamela-Sowińska, A. (2006). Rachunkowość od antropologii do międzynarodowych standardów [Accounting from anthropology to international standards]. In Kiziukiewicz, T. (Ed). Rachunkowość w zarządzaniu jednostkami gospodarczymi (133-139). Szczecin: Katedra Rachunkowości Uniwersytetu Szczecińskiego, Katedra Rachunkowości Akademii Rolniczej w Szczecinie.

Kaźmierczyk, J. (2008). Rol organizacionnoj kultury w polskom kommiercieskom bankowskom diele [The role of organizational culture in Polish commercial banking]. In Partycki, S. (Ed.), Kultura a rynek (519-522). Lublin: Wydawnictwo Katolickiego Uniwersytetu Lubelskiego.

Khan, M. (1994). Accounting issues and concepts for Islamic banking. International Conference on Developing Accounting Standards for Islamic Banks IIB I, London, 1994.

Maali, B., \& Napier, C. (2010). Accounting, religion and organizational culture: The creation of Jordan Islamic Bank. Journal of Islamic Accounting and Business Research, 1(2), 6-11.

MacArthur, J. B. (1996). An investigation into the influence of cultural factors in the international lobbying of the International Accounting Standards Committee: The case of E32, Comparability of Financial Statements. The International Journal of Accounting, 31(2), 213-237.

Moin, M. S. (2013). Financial performance of Islamic banking and conventional banking in Pakistan: A comparative study. International Journal of Innovative and Applied Finance, 1(1), 1-22.

Nobes, C. W. (1983). A judgmental international classification of financial reporting practices. Journal of Business Finance and Accounting, 10(1), 1-19.

Mill, J.S. (1882). A system of logic, ratiocinative and inductive. New York: Harper \& Brothers.

Mutahhari, M. (1993). Islamic economic. Teheran: Sadra Pub.

Nobes, C. W. (1998). Toward a general model of reasons for international differences in financial reporting. ABACUS, 34, 495-519.

Odongo, I. (2016). The influence of culture on judgement and decision making. International Journal of Advanced Legal Studies and Governance, 6(1), 1-21.

Perera, H., \& Baydoun, N. (2007). Convergence with international financial reporting standards: The case of Indonesia. Advances in International Accounting, 20, 201-224.

Roberts, C., Weetman, P., \& Gordon, P. (2005). International financial reporting, A comparative approach. Third Edition. London: Prentice-Hall.

Samad, A. (2004). Performance of interest-free Islamic banks vis-à-vis interest-based conventional banks of Bahrain. IIUM Journal of Economics and Management, 12(2), 1-15.

Shweder, R. A., \& LeVine, R. A. (1984). Culture theory: Essays on mind, self, and emotion. Cambridge: Cambridge University Press.

Stoner, J. A. F., Freeman, R. E., \& Gilbert, D. R. (2001). Kierowanie (Managing). Warsaw: PWE.

Ściborek, Z. (2003). Podejmowanie decyzji [Decision making]. Warsaw: Agencja Wydawnicza Ulmak. 
Malgorzata M. CZERNY, Marta MAZUROWSKA. A possible impact of cultural factors on the expectations on the content of Islamic financial statements

Swacha-Lech, M. (2010). Homo oeconomicus a homo neuropsychologicus jako element dyskusji o nowym paradygmacie finansów. Ku nowemu paradygmatowi nauk o finansach [Homo oeconomicus a homo neuropsychologicus as part of the discussion on the new financial paradigm. Towards a new paradigm of financial science]. Zeszyty Naukowe Uniwersytetu Ekonomicznego w Poznaniu, 144, 71-82.

Wach, K. (2010). Od człowieka racjonalnego do emocjonalnego. Zmiana paradygmatu nauk ekonomicznych [From a rational to an emotional man. A change in the paradigm of economic sciences]. Horyzonty Wychowania. Czasopismo Naukowe Wydziału Pedagogicznego Ignatianum w Krakowie, 9(17), 95-105.

Watts, R. L. (1992). Accounting choice theory and market-based research in accounting. British Accounting Review, 24, 235-267.

Watts, R. L., \& Zimmerman, J. L. (1979). The demand for and the supply of accounting theories: The market for excuses. Accounting Review, 54(2), 273-305.

Watts, R. L., \& Zimmerman, J. L. (1986). Positive accounting theory. New York: Prentice-HallEnglewood Cliffs.

Weber, E.U., \& Morris, M. W., (2010). Culture and judgement and decision making: The constructivit turn. Perspectives on Psychological Science, 5(4), 410-419.

Wojtyna, A. (2011). Czy w wyniku kryzysu finansowego ekonomia otworzy się bardziej na psychologię? [Will the economy be more open to psychology as a result of the financial crisis?] In Kozłowski, P. (Ed.), Węzet polski. Bariery rozwoju z perspektywy ekonomicznej i psychologicznej (169-184). Warsaw: Instytut Nauk Ekonomicznych PAN. Instytut Psychologii PAN.

Received: April 19, 2019

Accepted: June 29, 2019

Malgorzata M. Czerny

PhD, Assistant Professor, Poznan University of Economics and Business, Al. Niepodleglosci 10, 61-875 Poznan, Poland.

E-mail: malgorzata.czerny@ue.poznan.pl

Marta Mazurowska

$\mathrm{PhD}$, Assistant Professor, Poznan University of Economics and Business, Poland.

E-mail: marta.mazurowska@ue.poznan.pl 